\title{
PŘIROZENÁ RADIOAKTIVITA PALEOZOICKÝCH SEDIMENTŮ A CHEMISMUS KARBONÁTOVÝCH HORNIN NA MAPOVÝCH LISTECH 25-11 HLUBOČKY A 25-12 HRANICE
}

\author{
Natural radioactivity of Palaeozoic sediments and chemistry of carbonate rocks in the map \\ sheets 25-11 Hlubočky and 25-12 Hranice
}

\author{
Jiří Zimák 凸 \\ Katedra geologie PřF UP, tř. 17. listopadu 12, 77146 Olomouc
}

Key words: Horní Benešov Formation, Moravice Formation, Hradec-Kyjovice Formation, Hranice Devonian, gamma-spectrometry, dose rate

\begin{abstract}
This paper deals with natural radioactivity of Palaeozoic sedimentary rocks in the map sheets 25-11 Hlubockky and 25-12 Hranice. All studied rocks belong to the Moravo-Silesian Palaeozoic, namely to three flysch formations (Horní Benešov, Moravice and Hradec-Kyjovice fms.) and two carbonate formations (Macocha and Líšn fms.). Contents of potassium, uranium and thorium were measured using a laboratory gamma-ray spectrometer in 1337 rock samples, values of mass activity of ${ }^{226}$ Ra equivalent $\left(a_{m}\right)$ were calculated. The data are tabled and discussed. The average $a_{m}$ of analysed flysch sediments is $160 \mathrm{~Bq} . \mathrm{kg}^{-1}$. This value is very close to the value of $a_{m}$ calculated for the average continental crust. Natural radioactivity of flysch sedimentary rocks grows from psefites (conglomerates) through psammites (graywackes dominate) to the group of aleurites and pelites (siltstones, silty shales, clay shales). Natural radioactivity of the studied carbonate rocks is very low. In dark biodetritic limestones of the Lišen Fm. there were found slightly increased uranium contents (typically up to 6 ppm). Uranium in the rock is probably bound to graphitic matter.
\end{abstract}

Úvod

K základním fyzikálním parametrům přírodního prostředí patří jeho přirozená radioaktivita. Na ní se podílí i horninové prostředí. Tento článek hodnotí radioaktivitu paleozoických sedimentárních hornin na mapových listech 25-11 Hlubočky a 25-12 Hranice. Vychází z obsahů hlavních prirozených radioaktivních prvků (K, U a Th) stanovených laboratorní gamaspektrometrií $\mathrm{v}$ reprezentativních souborech horninových vzorků.

Paleozoické jednotky na mapových listech 25-11 Hlubočky a 25-12 Hranice a jejich horninová náplň

Paleozoické horniny vystupující na obou mapových listech jsou součástí moravskoslezského paleozoika. Na listu 25-11 Hlubočky je reprezentováno moravickým souvrstvím, v sv. cípu listu i hornobenešovským souvrstvím (Maštera et al. 1991). Moravické souvrství z listu 25-11 Hlubočky přechází na sousední list 25-11 Hranice, na němž je dále $\mathrm{k}$ východu vystřídáno hradecko-kyjovickým souvrstvím (Pálenský et al. 1996). Ve východním okolí města Hranice vystupují na relativně malém území paleozoické karbonátové horniny macošského a líšeňského souvrství (Pálenský et al. 1996; Pálenský 2002).

Hornobenešovské, moravické a hradecko-kyjovické souvrství jsou součástí spodnokarbonského flyšového komplexu (kulm), jenž je produktem sedimentace siliciklastického materiálu transportovaného turbiditními proudy (např. Dvořák 1994; Hartley a Otava 2001). Hornobenešovské souvrství je na hodnoceném území tvořeno

$\square$ jiri.zimak@upol.cz

DOI: https://doi.org/10.5817/GVMS2018-1-2-128 drobami (převážně jemnozrnnými), jílovými a siltovými břidlicemi a také siltovci (časté jsou rytmity). Moravické souvrství je budováno hlavně drobami (dominantně litickými) a rytmity, v nichž se stř́dají siltové nebo jílové břidlice se siltovci a jemnozrnnými drobami. Podřízeně jsou v moravickém souvrství přítomny konglomeráty (převážně gravelity). $\mathrm{V}$ hradecko-kyjovickém souvrství na listu 25-11 Hranice převažují psamity (litické droby, někdy arkózy) nad konglomeráty (petromiktní slepence $s$ drobovou matrix) a siliciklastiky s aleuritickou nebo pelitickou strukturou (siltové a jílové břidlice, siltovce často jde o rytmity).

Macošské souvrství je na listu 25-12 Hranice zastoupeno jen vilémovickými vápenci. Lišseňské souvrství v jejich stratigrafickém nadloží zde vystupuje jako „litologicky nesmírně pestrý komplex“ (Pálenský 2002), v němž jsou v následujícím textu rozlišovány tři litologické typy: a) mikritické hlíznaté vápence (typické křtinské vápence), b) stř́dání deskovitých vápenců s břidlicemi (kalciturbidity stratigraficky př́islušející k hádsko-říčským vápencům), c) lavicovité biodetritické vápence a vápencové brekcie (hádsko-říčské vápence).

\section{Materiál a metody}

Na mapových listech 25-11 Hlubočky a 25-12 Hranice bylo na 614 lokalitách odebráno 1337 vzorků paleozoických sedimentů. Determinace hornin byla prováděna jen makroskopicky. Proto ve skupině psamitů nejsou rozlišovány jednotlivé horninové typy (křemenné pískovce, droby apod.), z téhož důvodu jsou všechna siliciklastika s aleuritickou nebo pelitickou strukturou zařazena do skupiny aleurity + pelity. Makroskopické hodnocení hornin působilo komplikace $\mathrm{v}$ př́padě sedi- 
Tab. 1: Obsahy přirozených radioaktivních prvků $(\mathrm{K}, \mathrm{U}, \mathrm{Th}) \mathrm{v}$ horninách, vypočtené hodnoty hmotnostní aktivity ekvivalentu ${ }^{226} \mathrm{Ra}\left(\mathrm{a}_{\mathrm{m}}\right) ; \mathrm{n}=$ počet vzorků, $\mathrm{x}=$ průměr.

Tab. 1: Contents of the natural radioactive elements $(K, U, T h)$ in rocks, calculated mass activity of ${ }^{226}$ Ra equivalent $\left(a_{m}\right) ; n=n u m-$ ber of samples, $\mathrm{x}=$ average.

\begin{tabular}{|c|c|c|c|c|c|c|c|c|c|c|c|c|c|c|c|c|c|}
\hline \multirow{2}{*}{$\begin{array}{l}\text { list / geol. jednotka / } \\
\text { hornina }\end{array}$} & \multirow{2}{*}{$\mathbf{n}$} & \multicolumn{4}{|c|}{ K (hm. \%) } & \multicolumn{4}{|c|}{ eU (ppm) } & \multicolumn{4}{|c|}{ eTh (ppm) } & \multicolumn{4}{|c|}{ am (Bq.kg-1) } \\
\hline & & min. & $\max$. & med. & $\mathbf{x}$ & min. & $\max$. & med. & $\mathbf{x}$ & min. & max. & med. & $\mathbf{x}$ & $\min$. & max. & med. & $\mathbf{x}$ \\
\hline \multicolumn{18}{|c|}{ 25-11 Hlubočky - hornobenešovské souvrství } \\
\hline psamity & 21 & 1,1 & 2,5 & 1,6 & 1,7 & $<1,5$ & 5,3 & 2,2 & 2,4 & 7,1 & 13,0 & 10,7 & 10,5 & 82 & 184 & 128 & 130 \\
\hline aleurity a pelity & 9 & 2,2 & 3,7 & 2,8 & 2,8 & 1,6 & 4,2 & 2,7 & 2,8 & 9,6 & 12,5 & 11,4 & 11,3 & 137 & 199 & 167 & 168 \\
\hline \multicolumn{18}{|c|}{ 25-11 Hlubočky - moravické souvrství } \\
\hline psefity & 55 & 1,1 & 2,9 & 1,9 & 1,9 & $<1,5$ & 5,7 & 2,4 & 2,6 & 5,8 & 16,2 & 9,8 & 9,9 & 77 & 206 & 133 & 135 \\
\hline psamity & 306 & $<0,5$ & 3,8 & 1,9 & 1,9 & $<1,5$ & 21,2 & 2,6 & 2,9 & 3,6 & 33,9 & 11,1 & 11,9 & 41 & 439 & 144 & 150 \\
\hline aleurity a pelity & 178 & 1,1 & 4,0 & 2,6 & 2,6 & 1,6 & 9,8 & 3,6 & 3,8 & 7,1 & 31,6 & 12,3 & 12,9 & 100 & 326 & 178 & 183 \\
\hline \multicolumn{18}{|c|}{ 25-12 Hranice - moravické souvrství } \\
\hline psefity & 17 & 1,1 & 2,7 & 1,7 & 1,8 & 1,8 & 5,8 & 2,5 & 2,7 & 7,0 & 15,7 & 8,2 & 9,1 & 101 & 218 & 118 & 128 \\
\hline psamity & 109 & 0,7 & 3,3 & 1,7 & 1,8 & 1,0 & 5,8 & 3,2 & 3,3 & 6,2 & 24,3 & 12,8 & 12,8 & 74 & 239 & 154 & 158 \\
\hline aleurity a pelity & 104 & 1,8 & 4,3 & 2,8 & 2,9 & 2,8 & 20,2 & 4,7 & 5,1 & 10,0 & 58,2 & 13,8 & 15,1 & 140 & 689 & 209 & 220 \\
\hline \multicolumn{18}{|c|}{ 25-12 Hranice - hradecko-kyjovické souvrství } \\
\hline psefity & 90 & 0,6 & 2,8 & 1,4 & 1,4 & $<1,5$ & 4,4 & 2,1 & 2,1 & 5,0 & 14,0 & 8,1 & 8,4 & 63 & 194 & 108 & 110 \\
\hline psamity & 250 & 0,5 & 3,7 & 1,9 & 1,8 & $<1,5$ & 7,7 & 2,8 & 2,9 & 4,8 & 22,9 & 11,1 & 11,5 & 62 & 278 & 145 & 147 \\
\hline aleurity a pelity & 88 & 0,7 & 4,7 & 2,8 & 2,8 & $<1,5$ & 8,6 & 3,8 & 4,0 & 7,0 & 17,3 & 12,1 & 12,5 & 70 & 288 & 185 & 191 \\
\hline \multicolumn{18}{|c|}{ 25-12 Hranice - macošské souvrství (MS) a líšeňské souvrství (LS) } \\
\hline vápenec - MS & 14 & $<0,5$ & $<0,5$ & $<0,5$ & $<0,5$ & $<1,5$ & 1,5 & $<1,5$ & $<1,5$ & $<1,5$ & $<1,5$ & $<1,5$ & $<1,5$ & 26 & 32 & 26 & 28 \\
\hline vápenec - LS & 73 & $<0,5$ & 1,4 & $<0,5$ & $<0,5$ & $<1,5$ & 9,8 & 1,9 & 2,5 & $<1,5$ & 3,6 & $<1,5$ & $<1,5$ & 26 & 135 & 45 & 48 \\
\hline kalciturbidit (ca) - LS & 11 & $<0,5$ & 0,5 & $<0,5$ & $<0,5$ & $<1,5$ & $<1,5$ & $<1,5$ & $<1,5$ & $<1,5$ & 3,0 & 1,5 & 1,7 & 26 & 42 & 29 & 31 \\
\hline kalciturbidit (si) - LS & 12 & 0,5 & 2,6 & 2,1 & 1,9 & $<1,5$ & 1,8 & $<1,5$ & $<1,5$ & 4,5 & 8,3 & 6,8 & 6,6 & 51 & 128 & 103 & 99 \\
\hline
\end{tabular}

mentů na rozhraní aleurit/psamit, kdy např́íklad některé jemnozrnné droby mohly být považovány za siltovce a naopak.

V horninových vzorcích byly na PřF UP v Olomouci za použití gamaspektrometru SG - 1000 LAB s NaI(Tl) detektorem o objemu $0,35 \mathrm{dm}^{3}$ (průměr $76 \mathrm{~mm}$, délka $76 \mathrm{~mm}$ ) stanoveny obsahy K (přímo na základě koncentrace ${ }^{40} \mathrm{~K}$ ), U a Th (na základě dceřiných produktů, a proto jsou jejich obsahy při uvádění výsledků analýz označovány jako eU a eTh). Meze detekce: $\mathrm{K}=0,5 \mathrm{hm}$. \%, U a Th $=1,5$ ppm. Při výpočtu hodnot $\mathrm{a}_{\mathrm{m}}$ a $\mathrm{D}$ (viz níže) a př́i statistickém zpracování dat byly obsahy K pod mezí detekce nahrazeny hodnotou $0,33 \mathrm{hm} . \%$, obdobně v př́padě U a Th hodnotou $1 \mathrm{ppm}$. Před měřením byly horninové vzorky rozdrceny a uzavřeny do krabiček o objemu $250 \mathrm{ml}$, $\mathrm{v}$ nichž byly následně měřeny. Hmotnost takto připravených vzorků se pohybovala kolem 400 gramů. V případě vápenců líšeňského souvrství gamaspektrometrické analýzy doložily existenci rozdílů v obsazích U a Th mezi litologicky rozdílnými typy hornin, a to i přesto, že obsahy obou prvků byly převážně pod výše uvedenou mezí detekce (1,5 ppm). Proto byly provedeny další gamaspektrometrické analýzy vzorků vápenců líšeňského souvrství na témže prrístroji, avšak za nestandardních podmínek (hmotnost v rozpětí 700-1 000 g, neideální geometrie), umožňujících pro tento účel dostatečně přesné stanovení obsahů U a Th v intervalu 0,3 až 1,5 ppm.

Přirozená radioaktivita hornin je hodnocena na základě hmotnostní aktivity ekvivalentu ${ }^{226} \mathrm{Ra}\left(\mathrm{a}_{\mathrm{m}}\right)$ a též dávkového př́konu záření gama terestrického původu (D). Tyto parametry byly z výsledků gamaspektrometrických analýz vypočteny pomocí vztahů $\mathrm{a}_{\mathrm{m}}\left[\mathrm{Bq} \cdot \mathrm{kg}^{-1}\right]=$ $(0,077 \times 313 \mathrm{~K})+12,35 \mathrm{U}+(1,43 \times 4,06 \mathrm{Th}), \mathrm{D}\left[\mathrm{nGy} \cdot \mathrm{h}^{-1}\right]$
$=(0,043 \times 313 \mathrm{~K})+(0,427 \times 12,35 \mathrm{U})+(0,662 \times 4,06 \mathrm{Th})$, do nichž je obsah K dosazován v hm. \%, obsahy U a Th v ppm (Beretka a Matthew 1985; UNSCEAR 1988; Matolín a Chlupáčová 1997; Ngachin et al. 2007; Eštoková a Palaščáková 2013).

Údaje o chemismu vybraných vzorků karbonátových hornin byly získány pomocí energiově disperzního rentgenfluorescenčního (ED-XRF) analyzátoru DELTA-PREMIUM v laboratořích firmy URGA, s.r.o. se sídlem v Olomouci (použitou metodiku popisuje Zimák et al. 2016).

\section{Výsledky}

Výsledky všech gamaspektrometrických stanovení obsahů K, U a Th v horninových vzorcích jsou sumarizovány v tabulce 1 . Významné či zajímavé poznatky jsou komentovány v následující kapitole.

\section{Diskuze}

1. Údaje v tabulce 1 umožňují porovnat hodnoty $a_{m}$ jednotlivých horninových typů. Kdy však lze považovat konkrétní hodnotu $\mathrm{a}_{\mathrm{m}}$ za relativně vysokou nebo naopak nízkou? Možným kritériem je srovnání $\mathrm{s} \mathrm{a}_{\mathrm{m}}$ vypočtenou z klarků K, U a Th. Problémem je, že hodnota klarku publikovaná různými autory pro konkrétní chemický prvek se často výrazně liší jak v závislosti na kvantitě a kvalitě dat, tak i na způsobu jejich zpracování. Z klarků zveřejněných Goldschmidtem v roce 1937 (viz např. Bouška et al. 1980), kdy jde o 2,59 hm. \% K, 4 ppm U a 11,5 ppm Th, je za použití vztahů v kapitole „Vzorky a metody“ vypočtená $\mathrm{a}_{\mathrm{m}} 179 \mathrm{~Bq} \cdot \mathrm{kg}^{-1}$ (vypočtená $\mathrm{D}=87 \mathrm{nGy} \cdot \mathrm{h}^{-1}$ ). Rudnick a Gao (2005) pro svrchní část zemské kůry kontinentálního typu uvádí $2,80 \mathrm{hm}$. \% $\mathrm{K}_{2} \mathrm{O}(=2,32 \mathrm{hm}$. \% K), 2,7 ppm 


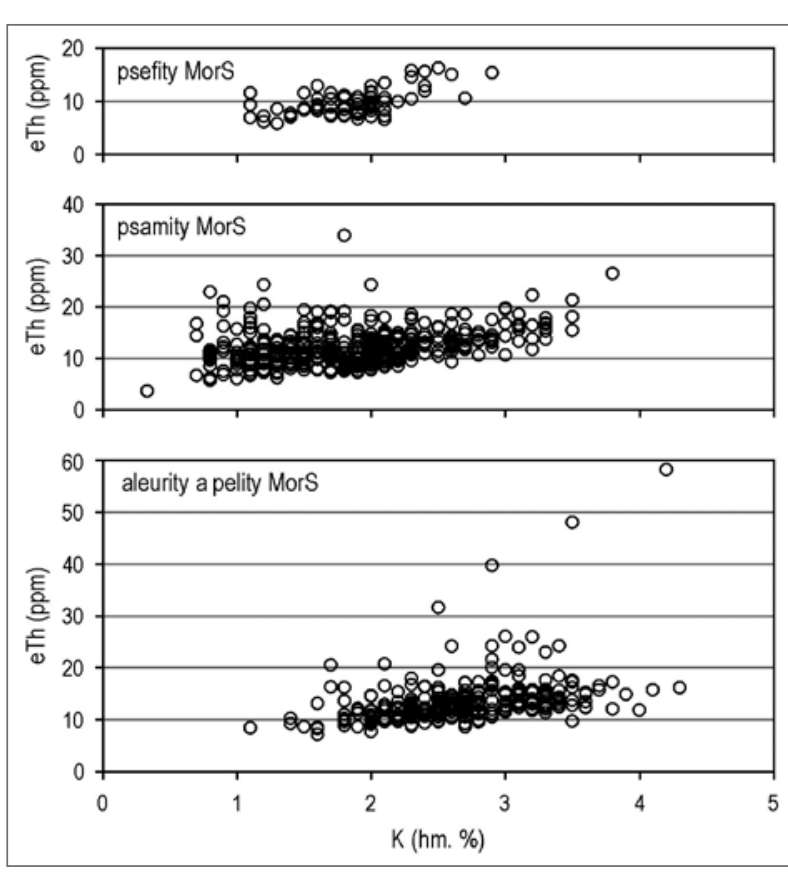

Obr. 1: Flyšové sedimenty moravického souvrství v diagramu draslík versus thorium.

Fig. 1: Potassium versus thorium diagram for flysch sediments of the Moravice Formation.

U a 10,5 ppm Th. Těmto klarkovým hodnotám odpovídá $\mathrm{a}_{\mathrm{m}} 150 \mathrm{~Bq} \cdot \mathrm{kg}^{-1}\left(\mathrm{D}=74 \mathrm{nGy} \cdot \mathrm{h}^{-1}\right)$. Z klarků publikovaných jinými autory (viz např. Rudnick a Gao 2005) lze samozřejmě odvodit jiné hodnoty $\mathrm{a}_{\mathrm{m}} \mathrm{a} \mathrm{D}$. Pro posouzení míry radioaktivity hornin na listech 25-11 Hlubočky a 25-12 Hranice byla zvolena hodnota $\mathrm{a}_{\mathrm{m}}$ kalkulovaná $\mathrm{z}$ klarků Goldschmidta (po zaokrouhlení 180 Bq. $\mathrm{kg}^{-1}$ ). Nutno doplnit, že průměrná hodnota globálního D je odhadována na 55 nGy.h-1 (UNSCEAR 1988; Manová a Matolín 1995), střední hodnota D pro území ČR je 65,6 \pm 19,0 nGy.h ${ }^{-1}$ (Manová a Matolín 1995).

Úroveň radioaktivity kulmských sedimentů na listech 25-11 Hlubočky a 25-12 Hranice je velmi blízká průměrné radioaktivitě zemské kůry kontinentálního typu. Vypočtená průměrná $\mathrm{a}_{\mathrm{m}}$ pro celý soubor 1227 vzorků kulmských siliciklastik je 160 Bq. $\mathrm{kg}^{-1}\left(\mathrm{D}=77 \mathrm{nGy} \cdot \mathrm{h}^{-1}\right)$. Karbonátové horniny macošského a líšeňského souvrství (celkem 110 vzorků) mají průměrnou $\mathrm{a}_{\mathrm{m}}$ jen $49 \mathrm{~Bq}$. $\mathrm{kg}^{-1}\left(\mathrm{D}=23 \mathrm{nGy} \cdot \mathrm{h}^{-1}\right)$.

2. Nejvyšší průměrné hodnoty $a_{m}$ ve všech třech flyšových souvrstvích byly zjištěny vždy ve skupině aleuritů a pelitů. To souvisí s vyššími průměrnými obsahy K, U a Th v této skupině hornin ve srovnání se siliciklastiky s psamitickou nebo psefitickou strukturou - viz tabulka 1 , v případě $\mathrm{K}$ a Th v sedimentech moravického souvrství též obrázek 1. Postupné zvyšování radioaktivity flyšových sedimentů moravskoslezského paleozoika $\mathrm{v}$ řadě psefit - psamit - aleurit + pelit již doložili naprr. Manová a Matolín (1989), Zimák a Štelcl (2004) a Zimák (2012). Růst $\mathrm{a}_{\mathrm{m}} \mathrm{v}$ této řadě

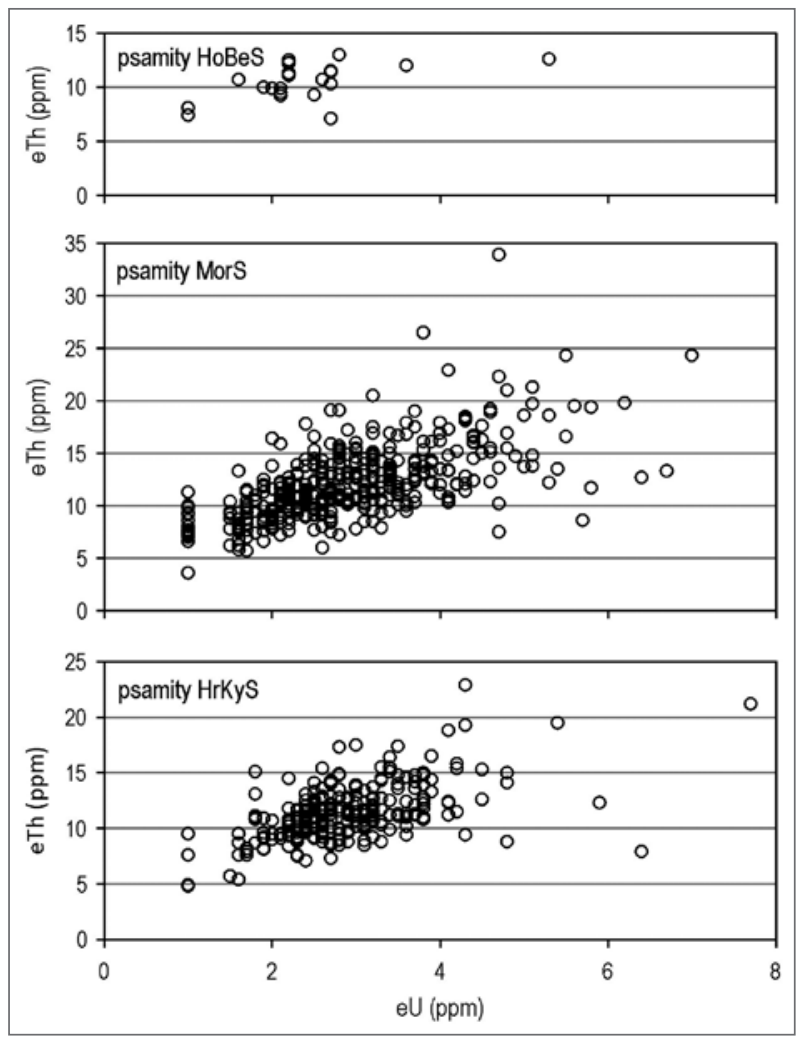

Obr. 2: Psamity hornobenešovského, moravického a hradecko-kyjovického souvrství v diagramu uran versus thorium.

Fig. 2: Uranium versus thorium diagram for psammites of the Horní Benešov, Moravice and Hradec-Kyjovice formations.

souvisí se snižováním obsahu klastického křemene a současně zvyšováním podílu fylosilikátů (takto lze vysvětlit růst obsahů $\mathrm{K}$ a Th) a též s často značným obsahem organické hmoty v čerstvě uložených sedimentech zrnitostně odpovídajících aleuritům a pelitům (lze předpokládat vazbu $U$ na neoxidovanou organickou hmotu, redistribuce U v průběhu diageneze a dalších procesech je však možná). Modální složení strukturně odlišných klastik a následně i jejich radioaktivita jsou ovlivněny jak procesy probíhajícími během transportu a sedimentace v turbi-
Tab. 2: Chemismus karbonátových hornin líšeňského souvrství, XRF analýza (celkové železo uvedeno jako $\mathrm{Fe}_{2} \mathrm{O}_{3}, \mathrm{n}=$ počet vzorků).

Tab. 2: Chemical composition of carbonate rocks of the Lišeň Formation, XRF analysis (total iron is presented as $\mathrm{Fe}_{2} \mathrm{O}_{3}, \mathrm{n}=$ number of samples).

\begin{tabular}{|c|c|c|c|c|c|c|}
\hline & \multicolumn{3}{|c|}{$\begin{array}{l}\text { křtinské vápence } \\
(\mathrm{n}=10)\end{array}$} & \multicolumn{3}{|c|}{$\begin{array}{l}\text { hádsko-říčské vápence } \\
\qquad(\mathrm{n}=21)\end{array}$} \\
\hline & minimum & maximum & průměr & minimum & maximum & průměr \\
\hline $\mathrm{CaO}$ (hm. \%) & 33,4 & 49,4 & 44,2 & 47,8 & 52,7 & 50,4 \\
\hline MgO (hm. \%) & $<2,0$ & $<2,0$ & - & $<2,0$ & 4,5 & - \\
\hline MnO (hm. \%) & 0,04 & 0,11 & 0,07 & 0,02 & 0,05 & 0,03 \\
\hline $\mathrm{SiO}_{2}(\mathrm{hm} . \%)$ & 4,2 & 21,4 & 9,5 & 1,0 & 3,6 & 1,8 \\
\hline $\mathrm{TiO}_{2}(\mathrm{hm} . \%)$ & $<0,07$ & 0,41 & 0,16 & $<0,07$ & $<0,07$ & - \\
\hline $\mathrm{Al}_{2} \mathrm{O}_{3}(\mathrm{hm} . \%)$ & 0,48 & 5,88 & 2,47 & $<0,40$ & 0,55 & - \\
\hline $\mathrm{Fe}_{2} \mathrm{O}_{3}(\mathrm{hm} . \%)$ & 0,83 & 2,70 & 1,33 & 0,22 & 0,40 & 0,28 \\
\hline $\mathrm{K}_{2} \mathrm{O}(\mathrm{hm} . \%)$ & 0,40 & 1,89 & 0,85 & $<0,15$ & 0,37 & 0,21 \\
\hline $\mathrm{P}_{2} \mathrm{O}_{5}(\mathrm{hm} . \%)$ & $<0,20$ & 0,37 & - & $<0,20$ & 1,39 & 0,32 \\
\hline $\mathbf{R b}(\mathrm{ppm})$ & 15 & 83 & 32 & $<10$ & 16 & - \\
\hline Sr (ppm) & 181 & 325 & 253 & 226 & 389 & 280 \\
\hline $\mathrm{Zr}$ (ppm) & 23 & 88 & 40 & 8 & 22 & 13 \\
\hline
\end{tabular}


ditních systémech, tak zcela zásadně i petrografickými poměry ve snosné oblasti (v př́padě jesenického bloku moravskoslezského kulmu na tuto skutečnost upozorňují již Zimák a Štelcl 2004; Zimák 2012).

3. Vysoké hodnoty $\mathrm{a}_{\mathrm{m}}$ byly zjištěny ve dvou vzorcích siltovců moravického souvrství z k. ú. Padesát Lánů s 4,2 hm. \% K, 20,2 ppm eU a 58,2 ppm eTh $\left(\mathrm{a}_{\mathrm{m}}=689 \mathrm{~Bq} \cdot \mathrm{kg}^{-1}\right)$ a $3,5 \mathrm{hm} . \% \mathrm{~K}, 17,7 \mathrm{ppm}$ eU a $48,0 \mathrm{ppm}$ eTh $\left(\mathrm{a}_{\mathrm{m}}=582\right.$ Bq. $\left.\mathrm{kg}^{-1}\right)$. Oba vzorky pochází z bloků šedočerného siltovce v deluviálních sedimentech. Na svahu v jejich okolí jsou hojné fragmenty i výchozy siltovců, vizuálně shodných, avšak v odebraných vzorcích bez anomálně vysokých obsahů U a Th. Nutno poznamenat, že siltovce a siltové (prríp. jílovo-siltové) břidlice s vysokými obsahy U a Th byly autorem zjištěny i $\mathrm{v}$ jiných úsecích moravického souvrství: na k. ú. Budišov nad Budišovkou a Guntramovice (mapový list 15-33 Moravský Beroun) a na k. ú. Klokočov u Vítkova (15-34 Vítkov). Vazbu U a Th v těchto horninách nelze objasnit bez provedení geochemického a mineralogického studia.

4. V souboru studovaných vzorků dominují psamity moravického a hradecko-kyjovického souvrství. V obou souvrstvích jde hlavně o droby, méně hojné jsou arkózy a křemenné pískovce. Psamity obou souvrství mají podobné intervaly obsahů $\mathrm{K}, \mathrm{U}$ a Th, a velmi blízké jsou i průměry - viz tabulka 1 a též obrázek 2 (do obrázku nebyl začleněn vzorek droby z moravického souvrství s anomálním obsahem 21,2 ppm eU). Proto i průměrné hodnoty $\mathrm{a}_{\mathrm{m}}$ jsou podobné: $152 \mathrm{~Bq} \cdot \mathrm{kg}^{-1}$ pro psamity moravického souvrství, $147 \mathrm{~Bq} \cdot \mathrm{kg}^{-1}$ pro psamity hradecko-kyjovického souvrství. Z hlediska obsahu K, U a Th lze psamity obou souvrství považovat za identické.

5. Karbonátové horniny macošského a líšeňského souvrství vykazují jen velmi nízkou přirozenou radioaktivitu (tab. 1). V př́ípadě kalciturbiditů líšeňského souvrství mají siliciklastické desky vyšší $\mathrm{a}_{\mathrm{m}}$ (v tab. 1 „si“) než karbonátové desky („ca“), a to díky výrazně vyšším obsahům $\mathrm{K}$ a Th vázaným na nekarbonátovou složku. V souboru 73 vzorků v tabulce 1 s označením „vápenec - LS“ jsou zastoupeny hlíznaté vápence (křtinské vápence) a tmavé biodetritické vápence a vápencové brekcie (hádsko-říčské vápence). Zřetelné rozdíly v chemismu obou skupin hornin dokumentují údaje v tabulce 2 , ukazující na značný podíl nekarbonátové složky v obou skupinách hornin, výrazně však vyšší v křtinských vápencích. Míru zastoupení nekarbonátové složky $\mathrm{v}$ analyzovaném souboru hornin lze vyjádřit pomocí obsahu zirkonia (obrázek 3 ukazuje pozitivní korelaci mezi $\mathrm{Zr}$ a SiO$\left.{ }_{2}, \mathrm{R}^{2}=0,96\right)$. Z obrázku 4 je zřejmý vztah mezi podílem nekarbonátové složky (vyjádřený pomocí Zr) a obsahy U a Th v obou litologických typech vápenců: obsah Th roste se zvyšujícím se obsahem $\mathrm{Zr}$ (tj. siliciklastického materiálu), obsah U na něm patrně nezávisí. Oba srovnávané litologické typy vápenců se liší pomerrem Th versus $U$ (obr. 5 , obsahy eTh pod 0,3 ppm jsou vyjádřeny hodnotou $0,2 \mathrm{ppm}$ ). V křtinských vápencích bylo stanoveno 1,0 až 3,6 ppm eTh a 0,4 až 1,6 ppm eU, v hádsko-ř́íčských vápencích $<0,3$ až 1,2 ppm eTh a 0,9 až 9,8 ppm eU. Je velmi pravděpodobné, že v hádsko-řričských vápencích jsou zvýšené obsahy U vázány na grafitickou

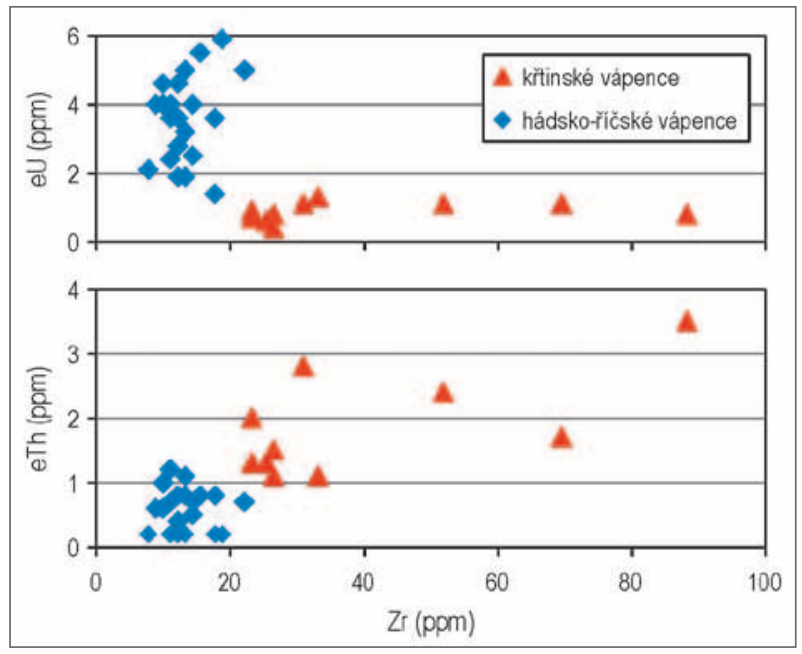

Obr. 3: Diagramy Zr versus Th a Zr versus U ve vápencích líšeňského souvrství.

Fig. 3: Diagrams of Zr vs. Th and Zr vs. U for limestones of the Líšeň Formation.

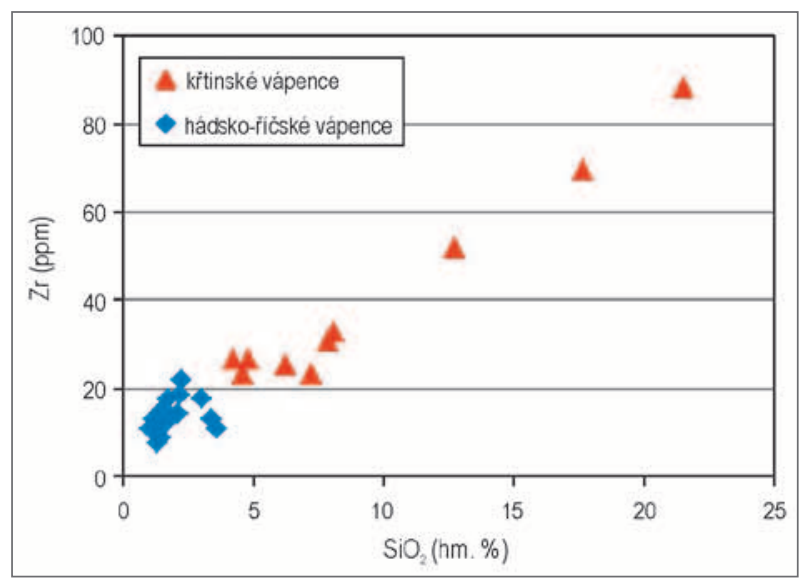

Obr. 4: $\mathrm{Graf} \mathrm{SiO}_{2}$ versus $\mathrm{Zr}$ ve vápencích líšeňského souvrství. Fig. 4: Graph of $\mathrm{SiO}_{2}$ versus $\mathrm{Zr}$ for limestones of the Líšen Formation.

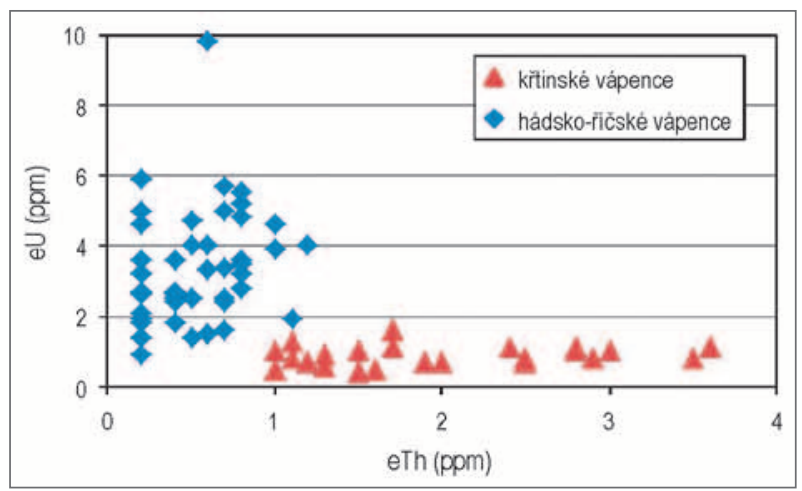

Obr. 5: Graf Th versus U ve vápencích líšeňského souvrství.

Fig. 5: Graph of Th versus $U$ for limestones of the Líšeň Formation.

substanci (obdobně jako v karbonátových horninách velkolomu Mokrá v jižní části Moravského krasu - např. Hladil 1999). Vazbu U na fosfáty lze na základě údajů o obsazích fosforu spíše vyloučit. Neexistuje ani náznak pozitivní korelace mezi eU a $\mathrm{P}_{2} \mathrm{O}_{5}$, i když obsahy fosforu 
jsou v hádsko-říčských vápencích někdy poměrně vysoké (viz tab. 2). Analogická situace je v prrípadě lavicovitých nebo deskovitých biodetritických hádsko-říčských vápenců ve velkolomu Mokrá: nekarbonátová složka vápence (tvořící 2 až $16 \mathrm{hm}$. \% horniny) obsahuje v průměru 0,35 hm. \% $\mathrm{P}_{2} \mathrm{O}_{5}$, max. 1,40 hm. \% $\mathrm{P}_{2} \mathrm{O}_{5}$ (Štelcl a Zimák 2014), tedy obsah fosforu v celé hornině je relativně nízký, koncentrace uranu jsou však v obdobném intervalu jako v biodetritických hádsko-říčských vápencích na listu 2512 Hranice, ani zde neexistuje závislost mezi obsahem uranu a fosforu.

\section{Závěr}

Flyšové sedimenty hornobenešovského, moravického a hradecko-kyjovického souvrství na mapových listech 25-11 Hlubočky a 25-12 Hranice vykazují průměrnou hmotnostní aktivitu ekvivalentu ${ }^{226} \mathrm{Ra}\left(\mathrm{a}_{\mathrm{m}}\right)$ na úrovni $160 \mathrm{~Bq} \cdot \mathrm{kg}^{-1}$. Jde o hodnotu velmi blízkou $\mathrm{a}_{\mathrm{m}}$ vypočtené pro průměrnou zemskou kůru kontinentálního typu. Ve všech třech flyšových souvrstvích byly nejvyšší obsahy $\mathrm{K}, \mathrm{U}$ a Th a následně nejvyšší hodnoty $\mathrm{a}_{\mathrm{m}}$ zjištěny vždy ve skupině aleuritů a pelitů (siltovce, siltové a jílové břid- lice). Karbonátové horniny macošského a líšeňského souvrství přítomné na listu 25-12 Hranice mají průměrnou $\mathrm{a}_{\mathrm{m}}$ jen $49 \mathrm{~Bq} \cdot \mathrm{kg}^{-1}$. V tmavých biodetritických hádsko-ř́ić ských vápencích líšeňského souvrství byly zaznamenány zvýšené obsahy uranu (běžně do 6 ppm), pravděpodobně vázané na grafitickou hmotu.

Přirozené radionuklidy v paleozoických sedimentech na mapových listech 25-11 Hlubočky a 25-12 Hranice jsou jedním ze zdrojů radiační zátěže obyvatelstva v této oblasti. Vzhledem k převážně relativně nízkým obsahům přirozených radioaktivních prvků by však ionizující záření pocházející z hodnocených hornin nemělo představovat žádné zdravotní riziko. Výjimkou jsou siltovce moravického souvrství s anomálně vysokými obsahy uranu (až 20 ppm) a thoria (až 58 ppm), které byly zjištěny jen na k. ú. Padesát Lánů. I na tomto území se siltovce s vysokou radioaktivitou vyskytují jen zcela lokálně, a to navíc v místech, kde není žádné trvalé osídlení.

\section{Poděkování}

Autor děkuje panu Mgr. Milanu Geršlovi, Ph.D. za poznámky a připomínky, které vedly ke zkvalitnění článku.

\section{Literatura}

Beretka, J., Matthew, P. J. (1985). Natural radioactivity of Australian building materials, industrial wastes and by-products. Health Physics, 48, 87-95. https://doi.org/10.1097/00004032-198501000-00007

Bouška, V., Jakeš, P., Pačes, T., Pokorný, J. (1980). Geochemie. Academia Praha.

Dvořák, J. (1994). Variský flyšový vývoj v Nízkém Jeseníku na Moravě a ve Slezsku. - Práce Českého geologického ústavu, 3. Český geologický ústav, Praha.

Eštoková, A., Palaščáková, L. (2013). Study of natural radioactivity of Slovak cements. - Chemical Engineering Transactions, 32, 1675-1680.

Hartley, A. J., Otava, J. (2001). Sediment provenance and dispersal in a deep marine foreland basin: the Lower Carboniferous Culm Basin, Czech Republic. - Journal of the Geological Society, 158, 1, 137-150. https://doi.org/10.1144/jgs.158.1.137

Hladil, J. (1999). Fyzikální stratigrafie vápenců v lomech Mokrá (gamaspektrometrická a magnetická měření). - MS, Geologický ústav Akademie věd ČR, Praha.

Manová, M., Matolín, M. (1989). Radioaktivita hornin ČSSR. In: Ibrmajer, J., Suk, M. et al.: Geofyzikální obraz ČSSR, 196-213. ÚÜG, Academia Praha.

Manová, M., Matolín, M. (1995). Radiometrická mapa České republiky 1 : 500 000. - Český geologický ústav, Praha.

Maštera, L., Tyráček, J., Otava, J., Cardová, E. (1991). Geologická mapa ČR 1 : 50 000. List 25-11 Hlubočky. - Český geologický ústav.

Matolín, M., Chlupáčová, M. (1997). Radioaktivní vlastnosti hornin. - In: Kobr, M. et al.: Petrofyzika, 109-126. Vydavatelství Karolinum, Praha.

Ngachin, M., Garavaglia, M., Giovani, C., Kwato Njock, M. G., Nourreddine, A. (2007). Assessment of natural radioactivity and associated radiation hazards in some Cameroonian building materials. - Radiation Measurements, 42, 61-67. https:// doi.org/10.1016/j.radmeas.2006.07.007

Pálenský P. (2002). Geologie území. - In: Müller, V. (ed.): Vysvětlivky k souboru geologických a ekologických účelových map př́rodních zdrojů v měřítku 1 : 50 000. List 25-12 Hranice, 7-23. - Česká geologická služba, Praha.

Pálenský, P., Č́́žek, P., Tyráček, J., Stráník, Z., Dvořák, J. (1996). Geologická mapa ČR 1 : 50 000. List 25-12 Hranice. - Český geologický ústav.

Rudnick, R. L., Gao, S. (2005). Composition of the continental crust. - In: Rudnick, R. L.: Treatise on geochemistry. Vol. 3 - The crust, 1-64. Elsevier, Amsterdam etc.

Štelcl, J., Zimák, J. (2014). Kvantita, chemismus a fázové složení nekarbonátového podílu v cementářských surovinách ve velkolomu Mokrá. - MS, Přírodovědecká fakulta MU Brno a Přírodovědecká fakulta UP Olomouc.

UNSCEAR, United Nations Scientific Committee on the Effects of Atomic Radiation (1988). Exposures from natural sources of radiation. Report to the General Assembly. - U. N., New York, USA.

Zimák, J. (2012). Přirozená radioaktivita kulmských sedimentů na východním okraji Českého masivu. - Geologické výzkumy na Moravě a ve Slezsku, 19, 1-2, 130-133. https://doi.org/10.5817/GVMS2012-1-2-130 
Zimák, J., Dalajková, K., Donocik, R., Krist, P., Reif, D., Štelcl, J., Kopecká, L. (2016). Využitelnost terénních rentgenfluorescenčních analyzátorů ke stanovení chemismu cementářských surovin - na př́kladu velkolomu Mokrá. - Zprávy o geologických výzkumech, 49, 79-82.

Zimák, J., Štelcl, J. (2004). Přirozená radioaktivita hornin moravskoslezského kulmu v oblasti Nízkého Jeseníku a Oderských vrchů: př́spěvek k poznání zdrojové oblasti klastického materiálu. - Geologické výzkumy na Moravě a ve Slezsku v roce 2003, 11, 103-106. 